14. Ticher S., Meyer M., Vodak R., Vetter E. Metodyi analiza teksta i diskursa. H.: Izd-vo Gumanitarnyiy TSentr, 2017. $356 \mathrm{~s}$.

15. Shveda Yu. Politychni partii Ukrainy: vyborchi partii chy vyborchi proekty? Parlamentski vybory 2012 roku v Ukraini: nauk. doslidzh. Kyiv: IPiEND im. I.F. Kurasa NAN Ukrainy, 2013. S. 88-94.

16. Sheygal E. Semiotika politicheskogo diskursa: monografiya. Volgograd: «Peremena», 2000. $328 \mathrm{~s}$.

17. Shchedrova H. Suchasna politychna leksyka: entsyklopedychnyi slovnyk-dovidnyk/I. Ya. Vdovychyn, L. Ya. Uhryn, H. V. Shypunov ta in.; za nauk. red. Khomy N. M. Lviv: «Novyi Svit-2000», 2015. 396 s.

18. Iakymenko Yu. Partiina systema Ukrainy u 2010-2015 rr.: zminy, tendentsii, perspektyvy evoliutsii. Derzhava i pravo: zb. nauk. prats. Kyiv: Vyd-vo «Iurydychna dumka», 2015. Vyp. 68. S. 181-193.

19. Iarosh Ya. Politychna konkurentsiia parlamentskykh partii : avtoref. dys. na zdob. nauk. stup. doktora. polit. nauk: 23.00.02 «Politychni instytuty ta protsesy». Lvivskyi. nats. un-t im. I. Franka. Lviv, 2019. 40 s.

DOI 10.31558/2617-0248.2020.5.5

УДК $81^{\prime} 272$

\title{
ОСНОВНІ НАУКОВІ ПІДХОДИ ЩОДО ОСМИСЛЕННЯ МОДЕЛІ МОВНОї ПОЛІТИКИ ЯК ПОЛІТОЛОГІЧНОГО КОНЦЕПТУ
}

\author{
ORCID ID: https://orcid.org/0000-0002-5728-0686 \\ Савойська С. В., доктор наук в галузі політології, професор МАУп
}

Досліджуються наукові підходи щодо осмислення моделі мовної політики як політологічного концепту, якими є: герменевтичне коло, за ознаками якого побудовано зазначену модель, складові якої єєдиним цілим, що складається з окремих секторів, які $є$ політичними мережами, котрі пов'язані між собою політологічними контекстами, тобто причино-наслідковими зв'язками; інституціональний, складовими якого є Інститут глави держави, парламент, уряд, суд, політичні партії, органи місцевого самоврядування, громадські організації, громадянське суспільство та ін. інституції; мережевий, який дає можливість з'ясувати, з яких політичних мереж складається модель, яка на етапах формування та здійснення мовної політики різними адміністраціями і державами, піддається змінам; геополітичний, завдяки якому з'ясовано, що суб'єкти російських та ін. політичних партій та громадських організацій ставлять за мету знищити Україну як суверенну державу, спираючись на російську мову, яка має отримати статус офіційної/державної, та російське населення, яке, на переконання окремих російських політиків і науковців, $є$ не національною меншиною у державах пострадянського простору, зокрема в Україні, а корінною нацією; ідеологічний, який є системою концептуально оформлених політичних, правових, релігійних, філософських уявлень, поглядів та ідей на політичне життя, які відображають інтереси, світогляд, ідеали, настрої людей, суспільства, політичних партій, громадських рухів та ін. суб'єктів політики, які конструктивно чи деструктивно впливають на будову моделі; ціннісний, який тісно пов'язано з мовою, ідеологією, самосвідомістю суб'єктів мовної політики, їх політичною культурою, вербальною та політичною поведінкою; синергетичний, який допомагає аналізувати модель через призму взаємодії її частин, яка за сутністю є конструктивною чи деструктивною; постмодерністський, породженням якого є мультикультуралізм, демократія, занепад комунізму, глобалізація, децентралізація тощо, які визначають вербальну, реальну та символічну поведінку політиків, окремі з яких гальмують процес здійснення мовної політики та негативно впливають на розбудову їі моделі. Акцентовано увагу на осмисленні «моделі мовної політики» як політологічного концепту, яка складається з політичних мереж та політологічних контекстів, які зв'язують її частини у складну конструкцію, які взаємодіють за принципом герменевтичного кола.

Визначено поняття «герменевтика», що є основою виникнення «герменевтичного кола» як явища $\mathrm{i}$ поняття, основою якого $є$ : пізнання мови і моралі, які регулюють поведінку суб'єктів мовної політики; розуміння змісту та значення політологічних контекстів і політичних мереж моделі мовної політики; політологічне знання, за допомогою якого досліджено закони, програми, наукові праці, історичні і політичні джерела, політичні рішення та явища, які вивчаємо, аналізуємо мовно-політичні ситуації та процеси.

Доведено, що кожен з підходів, який використано для осмислення зазначеної моделі, є важливим, позаяк усі вони у комплексі допомагають розглянути її будову та з'ясувати, що конструктивна чи деструктивна її суть залежить від режиму, який панує у державі, тобто форми правління та ідеології, 
які по-різному впливають на здійснення мовної політики, формування цієї складної конструкції та її розбудови.

Ключові слова: модель мовної політики, політологічний концепт, політичні мережі, герменевтичне коло, причино-наслідкові зв'язки, інституціональний, геополітичний, ідеологічний, синергетичний, постмодерністський

\section{Savoyska S. Basic scientific approaches to understanding the model of language policy as a political science concept}

Scientific approaches to understanding the model of language policy as a political science concept are studied, which are: hermeneutic circle, based on which this model is built, the components of which are a single whole, consisting of separate sectors, which are political networks interconnected by political science contexts, ie cause-and-effect relationships; institutional, which includes the Institute of the Head of State, parliament, government, court, political parties, local governments, NGOs, civil society and others. institutions; network, which makes it possible to find out which political networks make up the model, which at the stages of formation and implementation of language policy by different administrations and states, is subject to change; geopolitical, which clarified that the subjects of Russian and others. political parties and public organizations aim to destroy Ukraine as a sovereign state, relying on the Russian language, which should receive official / state status, and the Russian population, which, according to some Russian politicians and scholars, is not a national minority in the post-Soviet states, in particular in Ukraine, and the indigenous nation; ideological, which is a system of conceptually designed political, legal, religious, philosophical ideas, views and ideas on political life, which reflect the interests, worldview, ideals, moods of people, society, political parties, social movements and others. policy actors that constructively or destructively influence the structure of the model; value, which is closely related to the language, ideology, self-consciousness of the subjects of language policy, their political culture, verbal and political behavior; synergetic, which helps to analyze the model through the prism of the interaction of its parts, which is essentially constructive or destructive; postmodern, the product of which is multiculturalism, democracy, the decline of communism, globalization, decentralization, etc., which determine the verbal, real and symbolic behavior of politicians, some of which slow down the implementation of language policy and negatively affect the development of its model. Emphasis is placed on understanding the "model of language policy" as a political science concept, which consists of political networks and political science contexts that connect its parts into a complex structure that interacts on the principle of hermeneutic circle.

The concept of "hermeneutics" is defined, which is the basis of the "hermeneutic circle" as a phenomenon and concept, the basis of which is: knowledge of language and morality, which regulate the behavior of language policy; understanding the content and significance of political science contexts and political networks of the language policy model; political science knowledge, which is used to study laws, programs, scientific works, historical and political sources, political decisions and phenomena that we study, analyze linguistic and political situations and processes.

It is proved that each of the approaches used to understand this model is important, because they all together help to consider its structure and find out that its constructive or destructive nature depends on the regime prevailing in the state, ie the form of government and ideologies that differently affect the implementation of language policy, the formation of this complex structure and its development. Keywords: language policy model, political science concept, political networks, hermeneutic circle, cause-and-effect relations, institutional, geopolitical, ideological, synergetic, postmodern

Постановка проблеми. Мовна політика залишається складною проблемою у багатьох державах світу. Вона тісно пов'язана з минулим і сучасним держави, функціонуванням офіційних та неофіційних інститутів, режимом правління, ідеологією, політичною культурою та поведінкою суб'єктів політики, що формують модель мовної політики, яка $\epsilon$ складною конструкцією як узмістовному, так і сутнісному відношеннях. Вона складається з політичних мереж, що формуються на основі інститутів мовної політики, та політологічних контекстів, які їх зв'язують між собою причино-наслідковими зв'язками. Політичні мережі поєднуються між собою у складну конструкцію за допомогою політологічних контекстів, які водночас $є$ складовою політичних мереж,- усе це досліджується за допомогою конструктивного, деструктивного, герменевтичного, історикополітичного, інституційного та ін. підходів, напрямів і концептів, основними з яких є: «модель мовної політики», «політологічний контекст», «політичні мережі», «герменевтичне коло» та ін. Запропоновані підходи дають можливість більш повно і всебічно розглянути, проаналізувати та дослідити формування, розвиток і розбудову моделі мовної політики на етапах державотворення. Політичні мережі, як стверджує російська дослідниця Є. Саворська, у силу своєї гнучкості спроможні швидко пристосовуватися до умов правління та підвищувати якість політичного процесу, що дозволяє знайти шляхи вирішення проблем, що виникли [34, с. 63]. 
Аналіз останніх досліджень і публікацій. Основою формування моделі мовної політики як політологічного концепту є комунікативна політика, яка виникла на базі герменевтики. «Перші герменевтичні осмислення текстів, як зазначає вітчизняний дослідник О. Алексєєв, виникли як відповідь на запити грецької педагогіки та з необхідності тлумачення літературних, філософських, історичних, релігійних та ін. текстів» [1, с. 6]. Герменевтика, яка стосується історичних, соціальних, комунікативних, семантичних, культурних та ін. контекстів, зародилася, як вважає Г. Гадамер, в античності, зокрема в діалогах Платона та Аристотеля, які пов'язують інтерпретацію тексту з його розумінням [9, с. 5], цілісним сприйняттям та аналізом. 3 виникненням держави герменевтика як наука поширилася на інтерпретацію не лише релігійних, політичних, художніх, історичних та ін. текстів, а й на - відносин суб'єктів політики, їх політичну культуру, політичну поведінку, мовну політику, на основі якої формується модель. Одночасно зі створенням держави було сформовано офіційні (державні) та неофіційні (політичні і громадські) інституції, вивченню та аналізу діяльності яких вітчизняні науковці уваги майже не приділяють. Схожу думку з цієї проблеми має вітчизняний дослідник Л. Бунецький, який вважає, що методологія інституційного аналізу недостатньо використовується в українській політичній думці, а науковці практично не бачать різниці між класичним (традиційним) та новим інституціоналізмами [6, с. 60]. Представниками класичного (традиційного) інституціоналізму у першій половині XX ст. були Е. Баркер, Дж. Брюс, Т. Клоул, Г. Ласкі, К.Фрідріх та ін., які основну увагу приділяли дослідженню функціонування державних інституцій. Інститут мовної політики варто розуміти як формальне або неформальне об'єднання, основою створення якого є такі явища як мова і політика, суб'єкти якого здійснюють мовну політику, регулюють міжполітичні, міжетнічні, міжрегіональні та ін. відносини на державному та суспільно-політичному рівнях, захищають державну мову, національні інтереси та демократичні цінності. У другій половині 1980-х рр. на території Радянської України починають діяти неформальні правила політичної гри, які функціонують на базі формальних інститутів, що встановлюють, на думку Вольфганга Меркеля та Круассана Ауреля, перешкоди для ухвалення політичних рішень [26]. «Витіснення формальних інститутів неформальними, які подривають їх діяльність, як вважає В. Гельман, - одне з найпоширеніших наслідків посттоталітарних (посткомуністичних) трансформацій, які закріплюються у культурі суспільства, що задає відповідну траекторію розвитку інституційного середовища. У рамках культуралістського подходу неформальні інститути, як правило, ідентифікуються зі звичаями, традиціями та культурним обмеженням» $[10$, с. 6,7$]$.

Побудова моделі мовної політики вимагає конструктивної взаємодії політичних мереж та взаєморозуміння iї членів, які формують мовну політику та визначають іiі напрям як на мережевому, так і міжмережевому рівнях. Така взаємодія має бути присутня як у середині кожної політичної мережі, так i на міжмережевому, міжвладному, міжполітичному, міжфракційному, міжпартійному, міжрегіональному та ін. рівнях. Якщо політичні мережі, які зв'язані в одне ціле (модель) політологічними контекстами, є важливими складовими моделі мовної політики, а зазначена модель $є$ складовою мовної політики держави, то модель $є$ складовою світової мовної політики. Термін «політична мережа», яка є складовою мережевої структури, вітчизняна дослідниця С. Саворська разом з ін. науковцями розуміє як відносини між владою та групами інтересів [34, с. 10, 13]. Окрім неї, мережеві підходи до здійснення політики досліджували Джеремі Річардсон, Грант Джордан, Р. Емерсон, Д.Фельдман, які виходять з того, що кожна країна будує власну структуру моделі держави, влади і політики, зокрема і мовної. Політичні мережі, на їх думку, сформувалися на базі виникнення демократичних відносин та нового типу суспільства, а також- переосмислення ролі держави $\mathrm{i}$ мовної політики у нових умовах розвитку та збільшення впливу громадян на ухвалення мовно-політичних рішень. Це та ін. геополітичні підходи висвітлено у працях вітчизняних науковців, зокрема: П. Кир'якова, К. Лускалової, В. Литвиненко «Україна в російських геополітичних концепціях»; С. Кульчицького «Російська тінь на незалежності України», О. Майбороди та М. Панчука «Мовне та політико-ідеологічне протистояння в Україні: причини, чинники, прояви»; О. Майбороди «Російський націоналізм в Україні (1991-1998 рр.)», О. Чиркова «Явище російщення України у системі термінів українознавства», О. Мишанича «Закарпатський політичний сепаратизм: міфи і дійсність», Н.Ротар «Автономна Республіка Крим як цільова аудиторія впливу російського імперського націоналізму», В. Сквірської «Мова - зброя політики» або про мовні проблеми у пострадянській Одесі», О. Майбороди «Політичне русинство». Закарпатська версія периферійного націоналізму»; П. Гриценка «Мова як індикатор угорсько-українських відносин сьогодення», В. Скляра «Мовна асиміляція (російщення) українців у незалежній Україні», В. Лизанчука «Агресивність «русского міра» в інформаційному просторі України». Що стосується конценпції та водночас ідеології «русского міра», то історія іiі виникнення сягає, як вважає вітчизняна дослідниця О. Мельник, часів захоплення туркамиосманами Візантії 1453 р. «Тоді ідею православності, на іï думку, перехопило Московське царство. За таких умов Москва проголосила себе спадкоємицею одночасно Рима і Константинополя як центрів християнської віри і великих християнських держав та духовних святинь вселенського православ'я» [25, с. 312-313]. На сучасному етапі символом «русского міра» $є$ російська мова, яка в Україні $є$ політичною інституцією, котра за законом «Про засади державної мовної політики», який було скасовано 25 лютого 2018 року, мала статус регіональної. У цьому контексті варто зважити на думку I. Кресіної, яка звертає нашу увагу на суть націоналізму Росії, який полягає не лише у «збереженні загальноросійської державності, а у іiі спиранні на російську мову, «російське» православ'я та єдину «вищу» культуру, створену на російській основі, 
за підлеглого становища «нижчих» локальних, тобто неросійських культур» [22, с. 40]. Утім, політики і науковці, які симпатизують національно-демократичній ідеології, орієнтуються на Європейський Союз і НАТО, знайшли підтримку на Заході та переважно в Центрі України. 3 часом цю ідею підтримали мешканці, політики та науковці Сходу і Півдня Української держави, які почали відроджувати раніше заборонені окупаційними урядами, зокрема і російським, українську мову, культуру та ін.

Варто зазначити, що знецінення цінностей в українського народу пов'язано з втратою державності, неможливістю захищати національні інтереси і пріоритети, розвивати українську мову і культуру, які покликані зберігати єдність української нації та Української держави. Виходячи з зазначеного, однією 3 найбільших цінностей для українського народу є свобода, соборність і незалежність, які він, за окремими винятками, здобув у 1918 та на початку 1990-х рр., коли відновив державність, українську церкву, яка упродовж багатьох століть зберігала українську мову та українську культуру, які забороняли угорська, румунська, російська та ін. окупаційні адміністрації, котрі у різні часи панували на українських землях [36, с. 14, 16, 225]. На ціннісний підхід щодо аналізу політики спиралася вітчизняна дослідниця М. Остапенко, яка досліджує таке явище як плюралізм, який в одному випадку діє конструктивно, в іншому, спричиняє політичну кризу, мовнополітичні протистояння та конфлікти. Щоб захистити національні цінності, інтереси та ідентичність, у багатьох країнах, як констатують Г. Шевчук і Н. Трач, ухвалено нормативні акти, які підтримують охорону державної мови, а також створено відповідні інституції для здійснення внутрішньої мовної політики, які діють у Польщі, наприклад, Рада польської мови при Президії Академії наук; у Франції - це Французька Академія; в Ізраїлі - це Академія мови іврит [41, с. 97] тощо. Однією з важливих цінностей є вміння взаємодіяти і комунікувати, що досліджували вітчизняні науковці, зокрема Л. Бойко Бойчук, Ю. Кобець, В. Кремень та В.Ільїн, О. Микал та О. Снігир. Л. Мосионжник, М. Остапенко, А. Стьопін, О.Яковлев та ін. У добу постмодерну синергетика активно проникає в галузь освіти, де розв'язуються мовно-політичні проблеми та взаємозв'язок 3 життям. Синергетичний напрям у гуманітарних науках досліджували у ХX ст. французький філософ А. Пуанкаре та російські академіки А.Ляпунов, Н. Боголюбов, Н. Крилов, А. Колмогоров, А. Тихонов та ін. Їх послідовниками були Г. Хакен, І. Пригожин, В. Буданов та ін. Вперше термін «синергетика» використав у науковому дослідженні «Синергетика» наприкінці 60-х рр. XX ст. професор Штутгартського університету Г. Хакен для позначення нового наукового напряму, який займається вивченням процесів самоорганізації та взаємодії, які можна розглядати під конструктивним кутом погляду, який єднає, і деструктивним, що роз'єднує. Синергетичні зв'язки та взаємодія суб'єктів політики на мережевому та міжмережевому рівнях моделі мовної політики активно розвиваються у добу постмодерну. Уперше поняття «постмодерн» використав у 1917 році Р. Панвіц у праці «Криза європейської культури», де йдеться про нову людину, покликану подолати занепад, а також розглядається специфіка постмодернізму як культурного цивілізаційного явища $[11$, с. 3]. Мислителіпосмодерністи, зокрема Ж. Ліотар, Ж. Дерріда, Ж. Бодрійяр, Ж. Дельоз, П. Гваттарі та ін., розвінчують сутність тоталітарних режимів XX століття, їх ідеології, переосмислюють роль держави та значення політичної науки, зокрема й мовної політики.

Виклад основного матеріалу. Модель мовної політики як політологічний концепт - це конструкція, складовою якої $є$ політичні мережі, основою яких є інститути мовної політики та політологічні контексти, які зв'язують частини моделі у межах цілого (конструкту), формування та розбудова якого осмислюються за допомогою таких наукових підходів як:

1. Герменевтичний (герменевтичне коло), за принципом якого побудована модель мовної політики, складові якої пов'язані між собою так, де одне явище витікає з іншого та впливає на дії наступного. Феномен герменевтика, на основі якого створено поняття «герменевтичне коло», походить від імені Гермеса, який вважається Богом пізнання землі і неба. В античні часи герменевтику філософи використовували для перекладу і тлумачення текстів релігійного призначення. Їх досвід успадкували пращури українців (русичів), коли вони створили свою державу - Україну-Русь та прийняли християнство. 3 часом створена держава розпалася на окремі князівства, на основі окремих з них виникла Галицько-Волинська держава, яка у середині XIV ст. була захоплена сусідніми країнами. Українську державу було відновлено Б. Хмельницьким, а з часом приєднано до Московського царства. Якщо кожну з цих подій розглянути окремо, то побачимо, що виникнення (створення) держави та її втрата нагадують герменевтичне коло, де одне явище витікає з іншого та впливає на наступне. Спираючись на такий підхід, спробуємо пояснити процес виникнення та знищення (завоювання) Української держави, наприклад: існування Київського князівства та захоплення його новгородським князем Олегом; створення держави Україна-Русь на землях русичів (українців), розпад іiі на окремі князівства та знищення їх татаро-монгольськими племенами; виникнення Галицько-Волинської держави, захоплення іiі земель Великим Литовським князівством, Польщею та ін. державами; створення Української козацької держави «Військо Запорозьке», яке Богданом Хмельницьким було приєднано до Московії (з часом - Російська імперія); відновлення Української народної республіки (УНР) як незалежної держави, з часом захоплення іï Росією та створення СРСР; створення Української незалежної держави, анексія та окупація частини іiі території Росією на сучасному етапі українського державотворення.

Цю державницьку парадигму можна спробувати уявити увигляді такого герменевтичного кола: виникнення (створення) Української держави - захоплення (знищення) - відновлення (виникнення), де чітко відображено події, які рухаються по колу. Такі державотворчі зміни не існують окремо від мови, культури і 
політики, а тісно з ними пов'язані. Тому мовно-культурні надбання можна спробувати уявити у вигляді такого герменевтичного кола: виникнення руської (давньокиївської) мови, їі успадкування та розвиток у ГалицькоВолинській державі, заборона іiі використання Річчю Посполитою; збереження та поширення руської (староукраїнської мови) братськими школами, її розвиток під час існування Гетьманської держави, заборона української літературної мови Російською імперією; відродження української мови вітчизняною інтелігенцією, поширення їі в науці та художній літературі у ХIX ст.; використання та поширення української мови Центральною Радою, урядами Гетьмана П. Скоропадського та Директорії, заборона функціонування української мови у Радянській імперії; її відновлення та поширення у якості державної на сучасному етапі українського державотворення, гальмування використання української мови в анексованому Росією Криму та на окупованій території українського Донбасу.

Тобто, мовно-політичний процес, який є базою моделі мовної політики як політологічного концепту, осмислюємо у вигляді такого герменевтичного кола: виникнення мови русичів-українців, іiі розвиток і поширення, заборона, нищення, відновлення та гальмування. Як видно, в українській історії виникнення, розвиток та поширення української мови періодично змінюються ії гальмуванням, заборонами, нищенням та відродженням. На сучасному етапі здійснення мовної політики герменевтичне коло можна уявити у таких його формах: відновлення української мови національно-демократичними політичними інститутами сучасної України у статусі державної на поч. 1990-х рр. та гальмування іiі поширення на значній території країни проросійськи налаштованими інституціями.

2. Інституційний, завдяки якому досліджується діяльність формальних і неформальних інституцій та їх вплив щодо осмислення формування, розбудови або гальмування розвитку моделі мовної політики як політологічного концепту. Інституційний підхід- це: усвідомлене розуміння діяльності законодавчих, організаційних, судових, ідеологічних та ін. інститутів держави, спрямованих на регулювання та розв'язання мовно-політичних проблем; аналіз здійснення мовної політики на офіційному та неофіційному рівнях, яка забезпечує комунікативні зв'язки в усіх сферах і галузях суспільно-політичного життя держави та їх вплив на формування моделі; осмислення інституційних складових моделі, якими зазвичай $є$ російська, українська та ін. мови, які забезпечують в Україні комунікативні зв'язки на рівнях діяльності російськомовної, українськомовної та ін. освіти, проросійськи та проукраїнськи налаштованих партій, організацій, ЗМІ, політичних мереж та ін. Як вважає більшість науковців, інституції є формальні і неформальні, сутність і значення яких змінюються у залежності від політичного режиму, влади та ідеології, які панують у державі. На думку В. Кожевнікова, основою державної ідеології має бути національна ідея, без якої гальмується розвиток літератури, мистецтва, науки, культури, занепадають освіта і виховання та порушуються моральні принципи [20, с. 5]. Руйнували національні принципи та діяльність інститутів мовної політики за доби правління екс-Президента Л. Кучми, на думку Б. Білика, проросійські модифікатори, які під його головуванням створювали і ліквідовували комісії, комітети, відділи, ради 3 мовної політики та ін. мовно-політичні інституції, утім, при цьому жодна посадова особа не відзвітувала про роботу очолюваної нею структури [4, с. 161-162]. Модифікація [лат. modificatio - установлення міри] видозміна моделі мовної політики; гальмування поширення української мови як інституту державності на Сході і Півдні країни. На такій основі, за деякими винятками, не міг ефективно вибудовуватися конструктивний діалог між новою-старою владою (комуністами), яка об'єднана в одну політичну мережу, та опозицією (національно-демократичними політичними силами), яка являє собою іншу мовно-політичну мережу. На думку О. Пріцака, конструктивний діалог має будуватися на базі партнерства i рівності, a не на основі старшого і молодшого братів, тобто - пана і раба. 3 іншого боку, полярні політичні інституції та їх представники на перемовинах мають розпочинати дискусію без своїх «одвічних правд» [32, с. 107], позаяк у їх процесі вони мають відтворити феномен: шанувати думку один одного, дивитись правді в очі, якою б вона не була, та знайти спільну для всіх учасників правду, яка має бути прийнятною для кожної із сторін. Такий підхід щодо осмислення моделі мовної політики базується на демократичній ідеології, яка виявляє повагу до функціонування та розвитку не лише державної мови, а й мов національних меншин, до яких науковці, зокрема британський дослідник Білл Баурінг [2], відносять російську мову в Україні, а українську у Росії. Взаємодія, на думку Л.Климанської, яка, з одного боку, відбувається між владними та опозиційними суб'єктами політичних мереж, з іншого, між політиками і громадянами, є асиметричною, позаяк влада, опозиція і суспільство знаходяться у різних площинах та нерівних умовах, тому вільний обмін інформацією між ними ускладнений, а іноді й зовсім неможливий [19].

3. Мережевий, який дає можливість досліджувати формування моделі, що відбувається за принципом герменевтичного кола, де усе взаємопов'язано на мережевому та міжмережевому рівнях. Основою політичних мереж є інститути, діяльність яких залежать від того, яка ідеологія панує у державі. Якщо на державному рівні панує авторитарна, тоталітарна, комуністична ідеологія, то це буде один рівень діяльності і взаємодії членів політичних мереж та їх інституцій. Якщо на чолі держави панує національно-демократична ідеологія, то це буде інший рівень діяльності та взаємодії. Формування моделі мовної політики залежить від того, у якій державі (самостійній чи залежній) ця модель будується, яку мовну політику вона успадкувала від колишньої метрополії, та чи втручається остання у справи колишньої колонії. У цьому контексті модель мовної політики варто розуміти як таку, яка складається з таких політичних мереж, що формуються з державних та політичних 
інститутів. Такі офіційні (державні) інституції здійснювали мовну політику у добу Київської Русі, ГалицькоВолинської держави, Української козацької держави «Військо Запорозьке», Української народної республіки, Української Держави гетьмана П. Скоропадського, який, за твердженням російського дослідника А. Царинного, використовував українську мову, яка у його розумінні є жаргоном, у якості офіційної [37, с. 201, 205]. Українська мова в сучасній Україні відроджена у якості державної інституції.

4. Геополітичний, який активізують у своїх працях та розвивають у публічних виступах на користь Росії такі її політики і науковці як С. Бабурін, О. Дугін, Г. Зюганов, Д.Замятін, О. Смолін та ін. Вони намагаються довести, що між українцями і росіянами та їх мовами і культурами немає відмінностей, позаяк вони $є$ один i той самий народ, а українська мова $€$ штучним жаргоном та наріччям, який пронизано польською мовою. Про це йдеться у збірнику російських вчених, зокрема М. Смоліна, «Український сепаратизм у Росії. Ідеологія національного розколу» [37, с. 16]. Протилежну думку з цієї геополітичної проблеми має відомий вітчизняний науковець I. Дзюба, який вважає, що українська мова є основою культурної, наукової, соціальної, політичної та ін. комунікації українського народу. Лише через українську мову і культуру інші спільноти можуть пізнати український народ, зрозуміти його, об'єднатися навколо нього [15, с. 29] та моделі мовної політики. Проти російської геополітичної концепції виступає вітчизняна політологиня І. Кресіна, яка вважає їі тією основою, на якій сформувався російський націоналізм, який «базується на географічних та історичних «обгрунтуваннях» М. Трубецького. Тому і не дивно, що нинішні адепти «єдиної і неділимої» звертаються до ідейної спадщини слов'янофілів, що чітко простежується в обгрунтуванні російської національної ідеї, «місії» російської нації у програмних документах КПРС, монографіях та підручниках з геополітики О. Дугіна, С.Бабурина, О. Панарина, К. Гаджиєва та ін.» [22, с. 39]. I. Кресіна запевняє, що геополітична концепція Х. Макіндера, К. Хаусхофера, Н. Спікмена та ін. завуальована політичним замовленням, тому й не має нічого спільного з науковими доказами [22, с. 34]. Абсурд теорії російських науковців, як стверджують М. Пірен і В. Ребкало, полягає у тому, що розуміння ними культурного, мовного і духовного розвитку базується на власних політичних поглядах, які часто несумісні ні з духовністю, ні з культурою, [29, с. 232] ні з наукою. Виходячи з зазначеного, концепт «геополітика» займає важливе місце у структурі політичних мереж та інституцій російської моделі мовної політики, позаяк вона формується на основі асиміляції мов і культур неросійських народів СРСР та їх адаптації до російської культури, що досліджує російський науковець Д. Горенбург у праці «Політика та асиміляція радянських національностей» [12]. Взаємодія культур у такому разі відбувається не шляхом вільного розвитку, як мало б бути, а шляхом російщення мов національних меншин та корінних народів. Яскравим прикладом цього є депортація кримських татар у Туркменістан, Узбекистан та ін. регіони СРСР, а на їх місце було завезено етнічних росіян, яких, приміром, в АР Крим до його анексії Росією було понад 50\%, що досліджують Дж.Смагулова, В.Фієрман та ін. Проблемою автономії, за словами А. Колодій, було те, що серед випускників педагогічних вузів українською мовою володіли лише викладачі української мови і літератури [21, с. 210]. Щоб асимілювати мову і культуру завойованих народів, Російська імперія проводила жорстку мовну політику, нав'язуючи цим спільнотам державну/офіційну мову і культуру метрополії. Суть моделі мовної політики, яку протягом століть будує Росія в Україні та в ін. державах пострадянського простору, можна пояснити з огляду на їі кінцеву мету - повернути iii у своє лоно як територію, яка раніше входила до складу Московського царства, Російської імперії та колишнього СРСР, акцентуючи при цьому увагу на історичній справедливості та мовно-культурних інтересах [35]. В основу моделі мовної політики російські політики і науковці Росії, зокрема К. Затулін, О. Дугін та ін., поклали російську мову, яка є політичною інституцією в Україні, та російськомовне населення, що $є$ базою, на якій формується російська концепція «збирання земель», яка здійснюється шляхом захоплення чужих територій. Така геополітика, як зазначає І. Діяк, полягає: у поверненні та збереженні Росією єдиного мовно-культурного та релігійного просторів, наближенні українців до етнічних росіян, розмиванні українського етнічного моноліту штучною міграцією, в обмеженні економічного зростання України та ії ізоляції, у розчленуванні ії на окремі регіони та їх протиставленні, а також відокремленні Західної України від решти держави; денаиіоналізаџії українців, знищенні української мови і культури; в утриманні України у тілі Росії та ін. [16, с. 264-265].

Таку російську модель мовної політики в Україні підтримують суб’єкти політичної мережі, що об'єднувала такі політичні інститути, якими свого часу були Прогресивна Соціалістична партія, «Російські общини Севастополя», «Російські общини Криму» та ін., які, за висновком I. Діяка, докладали неабиякі зусилля, аби приєднати Україну до союзу з Росією, провести референдум з питань надання російській мові статусу державної, надати Луганській області статусу російської національно-культурної автономії, а місту Севастополь - російського федерального статусу та російського громадянства його мешканцям [16, с. 266]. На думку російського політика К. Затуліна, «усе це необхідно використати в особистих інтересах Кремля, аби реалізувати геостратегічний план Росії. I при цьому, як він вважає, зовсім неважливо, як до цього ставитиметься український народ, а важливо лише те, щоб ідея відновлення Великої Росії була досягнута, бо без України, на думку американського політолога, соціолога i державного діяча, колишнього радника з національної безпеки Президента Джиммі Картера, а також радника Центру стратегічних і міжнародних студій Зб. Бжезинського, Росія перестане бути євразійською імперією та залишиться лише азійською державою» [3, с. 2]. Тобто, модель мовної політики спирається на різні ідеології часом зовсім не сумісні, має 
різну мету і завдання. Зокрема, продуктивною і розвиваючою, на думку В. Іванишина, може бути лише така ідеологія, яка виростає з реальної проблематики життя поневоленого народу та є продовженням його визвольних традицій [18, с. 71$]$.

5. Ідеологічний підхід допомагає глибше осмислити концепт «модель мовної політики», який формувався у радянський період на комуністичній ідеології. Ідеологія - це: система переконань, ідей, поглядів на політичне життя суспільства, що відображає ідеали, світогляд, інтереси, настрої людей, класів, соціальних верств, політичних партій, громадських рухів; сукупність поглядів і цілей суб'єктів політики, що характеризують їх самосвідомість, відношення до дійсності, яка охоплює цінності, нормативні і цільові схильності та способи їх досягнення. У науковий обіг термін «ідеологія», увів французький філософ Д. Трасі у кінці XVIII - на поч. XIX ст., який його визначив як науку про ідеї [5, с. 131]. Ідеологія конструктивно чи деструктивно впливає на формування моделі мовної політики як політологічного концепту, який базується на ціннісно-нормативних, духовних та ін. атрибутах, а також - знаннях, ідеалах, почуттях суб'єктів політики та їх політико-поведінкових аспектах. Зокрема М. Костомаров, як ідеолог українського національного руху, у праці «Дві руські народності» доводить, що українці і росіяни - це різні народи, позаяк у політичній площині українці схильні будувати вільні союзи, засновані на рівноправності, починаючи від давньоруських міст-республік до козацьких формувань, а росіяни звикли до централізованих утворень 3 необмеженою владою, яка одноосібно здійснювала мовну політику у державі та вирішувала, якою мовою спілкуватимуться на території Росії неросійські за походженням народи. Водночас Х. Раковський з цього приводу зазначив, що завдання держави дати можливість розвиватися тій культурі, яку придушувала й обмежувала російська людина, яка ніколи не зазнавала національного гніту, а, навпаки, пригнічувала інші культури сотні років. У цьому сенсі I. Огієнко робить висновок, що «український народ - це вже дозріла нація, яка виборола літературну мову уважкій боротьбі з поневолювачами та зрослася з нею, тому уже ніколи від неї не відступить» [28].

Модель мовної політики, що формувалася в СРСР на основі комуністичної ідеології, була спрямована проти мов і культур етнічних меншин, корінних народів, зокрема й українського, а також - його рідної мови і культури. Подолати провінціалізм українців та звільнити їх від рабського наслідування російської мови і культури закликали Трохим Зіньківський та М. Хвильовий. Вони критикували радянську модель мовної політики і вважали, що російська мова не може бути орієнтиром для України, тому що вона «тяжіє над українцями у віках як господар становища, який привчив їх психіку до рабського наслідування. М. Хвильовий закликав «назавжди покінчити з контрреволюційною думкою будувати в Україні російську культуру», обстоював ідею звільнення від російської ідеології та впливу і наголошував на окремішності українського народу [14, с. 465]. Схожу думку щодо формування моделі мовної політики на національному грунті мав М. Скрипник, який боровся за самостійність української мови і культури та їх незалежність від Росії. Згідно 3 цим «російським можна вважати все, де присутня російська мова, не зважаючи на кордони та поширення російського етносу. М. Скрипник намагався модернізувати мовну політику на основі української мови і культури, сприяв проведенню українізації середньої та вищої школи, підготовці національних кадрів вчителів i викладачів, розвитку книговидавничої справи українською мовою. Він затвердив новий український правопис та проводив велику роботу щодо вироблення української наукової термінології. За представниками інших народів, які мешкали на території України, М. Скрипник визнавав право на культурну самобутність та здобуття освіти рідною мовою з поступовим переходом до вивчення української мови. Водночас він критикував заборони української мови і культури, імперську модель мовної політики та її ідеологію. На основі ідей М. Хвильового та Миколи Скрипника формувалася національно-демократична свідомість в українців. Зняття Миколи Скрипника з посади наркома освіти УРСР та звинувачення його у сприянні буржуазнонаціоналістичній лінії щодо створення української наукової термінології започаткувало, на слушну думку Н.Гавдиди та Л. Назаревич, новий етап у формуванні мовної політики, який можна назвати масштабним антиукраїнським терором [8, с. 78]. Усе це негативно позначилося на формуванні самосвідомості мешканців України, яка залежала від того, чия мова, культура та ідеологія панували на території держави у минулому. Ідеологія, на думку вітчизняного науковця Г. Шипунова, - це «сукупність взаємопов'язаних між собою ідей, націлених на впорядкування суспільно-політичних відносин. Водночас ідеї, які знаходяться в основі програм політичних партій, конструюють їх цілі» [42, с. 46]. Національно-демократична та авторитарна ідеології порізному впливають на самосвідомість суб'єкта мовної політики, на його політичну культуру, поведінку, ідентифікацією та комунікативну політику. На думку Ф.Рудича, ідеологію, яка тісно пов'язана з поведінкою суб'єкта мовної політики та його ідентифікацією, варто розуміти як одну з найбільш впливових форм політичної свідомості, що впливає на зміст відносин, масові та групові настрої [30, с. 182], а також - культуру та поведінку суб'єкта політики.

6. Ціннісний, який спрямовано на: формування моделі мовної політики на основі національних цінностей, якими є відродження української мови у статусі єдиної державної та її поширення в усіх сферах і галузях суспільно-політичного життя, що зумовлено державотворчим самовизначенням української нації; з'ясування мовно-політичної ситуації та мовно-політичних проблем, їх оцінку під кутом бачення справедливості, свободи та поваги до людської гідності. На цій основі модель мовної політики модернізувалася у добу Центральної Ради, Української Держави гетьмана П. Скоропадського, «українізації» 
та після проголошення України незалежною державою. Для цього необхідно шукати, на слушну думку О. Дьоміної, «соціокультурні, історико - цивілізаційні образи і категорії, які б несли потенціал політичного і морального єднання нації. Тобто, важливим завданням сучасного українського суспільства, яке спирається на сферу освіти i просвітництва, $\epsilon$, як вважає О.Дьоміна, виховання людини 3 активною, ціннісноорієнтованою і культурно-творчою позицією, яка здатна відстоювати інтереси нації» [17, с. 202].

Утім, цінності в уяві політиків та мешканців України є різними, позаяк вони тісно пов'язані з інтересами, які у різні часи формувалися під впливом таких держав як: Росія, яка у певний період часу панувала на Лівобережній Україні; Річ Посполита, котра мешканцям Правобережної України нав'язувала власні цінності, мову і культуру та забороняла українську; Австро-Угорщина, Румунія та ін., які на теренах України проводили жорстку політику та будували власну модель мовної політики. Ідейні цінності, як зазначає Г.Шипунов, пов’язані з культурними пріоритетами громадян, протидією глобалізації, євроінтеграційним та міграційним процесам, зі збереженням національної ідентичності та поверненням до традиційних цінностей [43, с. 71]. Не меншою цінністю для української нації є ії історія, національні герої, державні та національні символи, культура, звичаї, традиції та ін. Утім, таке явище як цінність кожна політична особа, група i спільнота розуміє по-своєму. Виходячи з зазначеного, одними з найбільших цінностей для українського народу є українська мова та українська культура, які є національними символами, позаяк вони дали назву державі, зберегли та розвинули звичаї і традиції українців. Національна символіка, як зазначає вітчизняна дослідниця Н. Хома, виражає уявлення про колективну спільноту «ми», а тому активно використовується у критичні моменти, які вимагають мобілізації суспільства, наприклад, під час українсько-російського збройного протистояння [39, с. 407].

Що стосується такого явища як єдність, то у цьому сенсі важливою для нас є мовна політика, яку здійснює Євросоюз, яка побудована на основі демократичних цінностей і свобод, що є позитивним прикладом для конструювання мовно-політичних моделей у тих державах, які стали на шлях плюралістичного i мультилінгвального розвитку. Модель Євросоюзу варто розуміти як конструкт, мовна політика якого базується на розумінні, єдності євроспільнот та європейських стандартах, які втілюються у життя на основі мультикультурної та інституціональної методологій, за допомогою яких досліджуються демократичні і національні цінності цього союзного об'єднання [33, с. 316]. Варто звернути увагу також і на те, що модель мовної політики Свросоюзу підходить не усім поліетнімним та багатонаціональним державам, позаяк багато залежить від того, якою була раніше мовна політика союзної держави, що є членом Свросоюзу, які відносини склалися між частинами іiі мережевого конструкту, яка мовна політика проводиться на сучасному етапі державотворення, які цінності та інтереси захищають ii державні і політичні інституції. Якщо виходити з філософії американського дослідника Дж. Д'юї, то цінність, як актуалізує увагу Т. Лапіна, - це не просто об'єкт інтересу, а результат діяльності людини і держави в цілому, який складається з умов виникнення інтересу, об'єкта його спрямованості та бажаного результату [23].

У цьому сенсі варто зконцентрувати увагу на ціннісному підході щодо формування моделі мовної політики такої держави як Франція, інтереси якої замкнулися на демократичних та національних цінностях французької нації, якими є французька мова, яку Королівський ордонанс у 1539 році наказав використовувати в усіх сферах і галузях суспільно-політичного життя, зокрема у судових паперах [13, с. 29]. Таким чином французька мова поширилася в усіх провінціях цієї держави, зокрема Фландрію (1684 р.), Ельзац (1685 р.), Руссильйон (1700р.), німецьку Лотарингію (1748р.), Корсику (1768 р.) та ін. Зважаючи на це, 12 млн. французів з 25 не знали французької мови і не могли нею вільно спілкуватися. Внаслідок запровадження монолінгвальної моделі мовної політики упродовж XIX ст. французька мова була поширена в усіх регіонах країни і галузях іiі суспільно-політичного життя, зокрема, у військовій, освітній, книговидавничій, інформаційній та ін. [33, с. 385]. Тобто, у мовно-політичному досвіді цієї держави $\epsilon$ позитивні складові, що може бути застосовано для побудови моделі мовної політики на національній та конструктивній основах в Україні.

7. Синергетичний, який $є$ актуальним щодо дослідження взаємодії складових моделі мовної політики як на мережевому, так і міжмережевому рівнях. Концепт «синергетика» (грец. synergetikos - спільна дія, узгоджено діючий) - спільна погоджена дія, у якій зацікавлені національно-демократичні політичні інституції та українська інтелігенція, які: відроджують україномовну освіту, історію України та українську культуру протягом XIX - на поч. XX ст.; поширюють українську мову у статусі державної в усіх сферах і галузях суспільно-політичного життя, зокрема й на сучасному етапі державотворення; здійснюють модернізацію освіти на україномовній основі, без чого українські політики не змогли б закріпити українську мову як єдину державну у Конституції України та ухвалити ряд законодавчих актів і програм, які регулюють мовну політику на державному рівні, у ЗМІ, на телебаченні та ін. галузях і сферах суспільно-політичного життя. Стратегічним завданням модернізації освіти $\epsilon$, на думку І. Лопушинського, вивчення української мови в усіх навчальновиховних закладах, поширення комунікації цією мовою та утвердження іiі як основної мови функціонування у загальноосвітній, професійній та вищій школі [24, с. 19]. Деструктивна взаємодія «лівих» і «правих» політичних інститутів призводить до негативних наслідків, які заподіюють шкоду формуванню моделі мовної політики на конструктивній основі. За визначенням Г. Шипунова, «ліві» інституції виступають за рівність людей у суспільстві, а «праві» відстоюють соціальну нерівність [43, с. 69]. 3 такою позицією можна 
погодитись, якщо вона не стосується мовно-політичних проблем, де національно-демократичні політичні сили, на відміну від «лівих» політичних інституцій, відстоюють формування та розбудову моделі мовної політики на національній основі. Це ми відстежуємо під час вивчення, аналізу та ухвалення законів, зокрема «Про ратифікацію Європейської хартії регіональних мов або мов меншин» та «Про засади державної мовної політики», які було проголосовано проросійськи налаштованими депутатами Верховної Ради без належного обговорення та 3 порушенням процедури ухвалення.

8. Постмодерністський, який виник у кінці 1960 - х рр. на основі модернізму [франц. моdernisme сучасний], що був напрямом у політиці з кінця XIX та у першій пол. XX ст. У цьому контексті постмодернізм [лат. post - після, що означає те, що настає після чогось], розуміємо як: новий етап розбудови моделі мовної політики, який в останні десятиліття спричинив широкі дискусії, породив нові концепції і теорії; новий напрям у політологічній теорії, яка намагається під іншим кутом бачення пояснити мовно-політичні явища і процеси, які формують реальність у вигляді постіндустріального суспільства; теорію, яка визначає нові стратегії, цілі й завдання розвитку моделі мовної політики та політичної науки загалом. В умовах постмодерну заперечуються ідеологія, практика насилля, війни на користь плюралізму, мультилінгвізму, демократії та ін. Утім, «сучасна реальність, на думку А.Постол, свідчить, що постмодернізм і глобалізація, «підточуючи» підвалини модерної держави, руйнують національну ідентичність як одну з основ згуртованості суспільства і держави» [31, с. 74]. На слушну думку А. Черниш, «сучасному українському суспільству глобалізація загрожує ззовні, а регіоналізація і федералізація - з середини» [40, с. 16]. У цьому сенсі мультикультуралізм варто розуміти як мовно-культурна політика держави, яка протиставляється ідеї «плавильного котла» і грунтується на визнанні та збереженні культурних відмінностей у межах однієї держави. А оскільки мультикультуралізм виник по суті у постмодерну добу, то постмодерністи дійшли висновку, що лояльність громадян до своєї держави багато у чому забезпечується добробутом, який вони бачать у зростанні економіки, ідентичності, взаєморозуміння, які спрямовано на побудову конструктивної моделі мовної політики. Тобто, постмодернізм розлучається із тоталітаризмом та переходить до ідеї мовно-політичної різноманітності. Цей перехід може бути конструктивним, якщо спиратиметься на раціональне мислення у контексті побудови моделі мовної політики. Тут варто погодитися з цитатою вітчизняних дослідниць Н.Степанової та Ю. Андрієнко, які констатують, що «українське суспільство, не встигнувши адаптуватися до модерних вимог політики, а саме: свідомого виконання людиною громадських обов'язків, вироблення дієздатних інституціональних форм суспільного контролю за владою, добровільного взяття на себе відповідальності за той політико-правовий порядок, який виник як результат взаємодії суспільства і влади, потрапило у ситуацію постмодерну» [38, с. 126], яка характеризується мовно-політичними проблемами, конфліктами та сепаратизмом. «Конфліктність мовних проблем сучасна Україна успадкувала, на слушну думку Н. Гавдиди і Л. Назаревич, від колоніального минулого, під час якого російська мова відтіснила українську у значній частині східних і південних областей Української держави, перебравши на себе основну функцію мови - комунікативну, яка послаблює національну самосвідомість українців, перешкоджаючи побудові міцної незалежної держави» [8, с. 79]. 3 іншого боку, постмодернізм, який характеризується відходом від ідей і цінностей попередньої доби, та у порівнянні з нею, є більш прогресивним, відкритим та плюралістичним. Зокрема, французький філософ, постмодерніст, деконструктивіст Жак Дерріда зробив спробу переосмислити традиційні цінності та стереотипи мислення. Тому його знаки набувають політичного характеру шляхом мови і мовлення, вказують на реальний предмет або на його заміщення знаком [27]. У цьому сенсі знаки, явища, візуалізація, політична поведінка та політичні дії епохи постмодернізму, як звертає увагу вітчизняна дослідниця Н. Хома, асоціюються 3 «невизначеністю, відсутністю канонів, карнавалізацією, посиленням самовираження людини» та ін. [39, с. 405]. Схожу думку з цієї проблеми мають Н.Степанова та Ю. Андрієнко, які вважають, що «постмодерній українській культурі притаманні падіння поваги до влади («Революція гідності»), посилення самовираження людини (використання технологій, які сприяють карнавалізації протестних акцій), «засліплення грою символів» (флешмоби, перфоманси, театралізація), віртуалізація (вибори, під час яких боротьба ідей і програм заміщується боротьбою політичних шоуменів за кількість глядачів/читачів, лайків, повідомлень у соціальних мережах), перетворення політики на «ток-шоу» [38, с. 126-127]. Усе це, на думку О. Вишняк, не сприяє конструктивній розбудові моделі мовної політики, а, радше за усе, наближає час до найшвидшої іiі демонтажу або перетворення. Тим більше, якщо зважити, що віртуалізація політична - це процес заміщення політичної реальності системою образів, уявних моделей, симуляцій, спираючись на масмедіа, які конструюють соціально-політичну реальність, програмують сьогодення, а також майбутню поведінку громадян [7, с. 44].

Таким чином, кожний із використаних підходів допоміг осмислити модель мовної політики як політологічний концепт під таким кутом бачення як: синергетичний, мережевий та герменевтичний, які дають можливість дослідити ті процеси, що відбуваються на комунікативному, поняттєвому, поведінковому та ін. рівнях; ідеологічний, геополітичний, інституційний та постмодерністський, які дають можливість зосередити увагу на мові, культурі і тих інституціях, що пов'язані з діяльністю проукраїнськи або проросійськи налаштованих політиків та їх політичних сил, одні з яких будують модель мовної політики на національній основі, інші, - проросійській, проугорській, прорумунській та ін. 


\section{Бібліографічний список:}

1. Алексєєв О. Політична герменевтика як метод політологічного дослідження: Автореф. дис. ... канд. політ. наук: 23. 00. 01 / Дніпропетровський національний університет імені Олеся Гончара. Дніпропетровськ, 2008. $20 \mathrm{c}$.

2. Bowring B. Language rights in practice - the case of the former editor of the only Khakas language newspaper / Lukanovic S. N. (ed.). A Shared Vision: Intercultural Dialogue - A Global Paradigm to Promote Linguistic and Cultural Diversity. Ljubljana, Slovenia: Slovenian National Commission for UNESCO, Institute for Ethnic Studies. 04 Nov. 2010. P. 87-106.

3. Бжезинський 3. «Наступною «гарячою точкою цілком може стати Україна». Голос України. 15. 08. 08. C. 2 .

4. Білик Б. Проблеми державної мови в Україні (1989-2004 рр.). Збірник наукових праць Науководослідного інституту українознавства. К.: Поліграфічний центр «Фоліант», 2005. T.VI. С. 160-164.

5. Брацкі А. Українське мовне питання чи питання української мови - соціо-психокультурний аспект. К.: Центр українознавства Київського національного у-ту ім. Т. Шевченка, 2012. Вип. 8. С. 86-89.

6. Бунецький Л. Аспекти інституціоналізму в сучасній політичній науці: аналіз феномену «політичний інститут». Вісник Київського національного університету ім. Т. Шевченка. Серія Філософія. Політологія. Вип. 91-93. 2009. С.60-64.

7. Вишняк О. Ставлення українських громадян до питання про статус мов у державі. Мовна ситуація в Україні: між конфліктом і консенсусом. К.: ІПіЕНД імені І. Ф. Кураса НАН України. 2008. С. 144-157.

8. Гавдида Н., Назаревич Л. Лінгвоцид як форма мовної політики. Наукові записки ТНПУ. Серія: Мовознавство. Вип. ІІ(24) 2014 78. С. 77-80.

9. Гадамер Г. - Г. Герменевтика і поетика / Г. - Г. Гадамер; пер. 3 нім. К.: Юніверс, 2001. 288 с.

10. Гельман В. Институционное строительство и неформальные институти в современной российской политике. Полис. Политические исследования. 2003. №4. С. 6-25.

11. Горбатенко В. Постмодерн і трансформація ціннісної основи людського буття / В. Горбатенко. Політичний менеджмент. Київ, 2005. №1. С. 3 - 13 .

12. Gorenburg D. Soviet Nationalities Policy and Assimilation / D. Arel, B. Ruble (eds.). Rebounding Identities: The Politics of Identity in Russia and Ukraine. Baltimore M D: Johns Hopkins University Press, 2006. P. 273-303.

13. Данилевська О. Мова в революції та революція в мові: мовна політика Центральної Ради, Гетьманату, Директорії УНР/Оксана Данилевська. К., 2009. 176 с.

14. Дербишайр Дж. Д., Дербишайр Я. Политические системы мира: В 2-х т. Том 1: Пер. 3 англ. М.: РИПОЛ КЛАССИК, 2004. 512 с.

15. Дзюба I. Що за обрієм? (наша культурна спадщина і культурне майбуття) / Дзюба I. Україна: культурна спадщина, національна свідомість, державність. Київ: Наукова думка, 1992. Вип. 1. С. $225-230$.

16. Діяк І. Українське відродження чи нова русифікація?: Наукове видання. К.: Гранослов, 2000. 304 с.

17. Дьоміна О. Аксіологічні основи національної ідеї/ О. Дьоміна. Гілея: науковий вісник. 2015. Вип. 93. С. 201-205.

18. Іванишин В. Нація, державність, націоналізм. Дрогобич: Відродження, 1992. 175 с.

19. Климанська Л. Комунікативний потенціал у політиці / Лариса Климанська. Українська національна ідея: реалії та перспективи розвитку: [збірник наукових праць] / Національний університет «Львівська політехніка» [та інші]. - Львів: Видавництво Національного університету «Львівська політехніка», 2006. Випуск 18. С. 104-109.

20. Кожевніков В. Важкий шлях до рідної мови. Київ, 2005. 27 с.

21. Колодій А. Національний вимір суспільного буття. Львів: Астролябія, 2008. 368 с.

22. Кресіна І. Українська національна свідомість і сучасні політичні процеси: (Етнополітичний аналіз): [Монографія]. К.: Вища школа, 1998. 392 с.

23. Лапіна Т. Ідентифікація культури: філософські критерії. Філософія і культура. 2013. № 10. C. $1407-1418$.

24. Лопушинський I. Формування та реалізація державної мовної політики в галузі освіти України: Автореф. дис.... докт. політ. наук: 25. 00. 02 / Національна академія державного управління при Президентові України. К., 2008. 30 с.

25. Мельник О. «Перший і третій Рим» в контексті ідеології «Русского мира» і верифікації сучасного Ватикану / О. Мельник. Українське релігієзнавство. 2015. № 73. С. 311-319.

26. Меркель В. Формальные и неформальные институты в дефектных демократиях / В. Меркель, А. Круассан. Политические исследования. 2002. №2. С.20-31.

27. Новакова О. Параметри конструктивної взаємодії політичних сил/О.Новакова. Науковий часопис НПУ імені М. П. Драгоманова. Серія 22: Політичні науки та методика викладання соціально-політичних дисциплін. 2014. Вип. 15. С. 3-8.

28. Огієнко І. Історія української літературної мови. К.: Наша культура і наука, 2004. 436 с. 
29. Пірен М., Ребкало В. Духовність особистості- основна цінність демократичного суспільства / М. Пірен, В. Ребкало. Вісник Національної академії державного управління при Президентові України. 2011. Вип. 2. С. 228-236.

30. Політико-ідеологічний процес в українському суспільстві в умовах модернізації: порівняльний аналіз. [Монографія] / За заг. ред. Ф. М. Рудича. К.: ІПіЕНД ім. І. Ф. Кураса НАН України, 2013. 448 с.

31. Постол А. Постмодернізм як сучасна суспільно-політична реальність / А. Постол. Гуманітарний вісник ЗДІА. Запоріжжя, Вип. 42. 2010. С. 69-79.

32. Пріцак О. Замість монологів і полемік - творчий діалог. Віче. 1994. №4 (25). С. 98-107.

33. Савойська С. Політологічний контекст моделі мовної політики: теоретико-методологічний аналіз [Текст]: монографія / Світлана Савойська; Львів. нац. ун-т ім. Івана Франка. Львів: Простір-М, 2019.790 с.

34. Саворская Е. Политические сети в процессах надгосударственного регулирования: европейский и мировой опыт. М.: ИМЭМО РАН, 2018 с.

35. Smagulova J. «Language policies of kazakhization and their influence Smagulova S. J Iternational journal of bilingual education and bilingualism. 2008. 19 Dec. Vol. 11. Issue 3-4. P. $440-475$.

36. Українське питання в Російській імперії (кінець XIX - поч. XX ст.): Колективна наукова монографія в трьох частинах. Частина 3. Київ: Інститут історії України НАН України, 1999. 276 с.

37. Смолин М. «Украинский туман должен рассеяться, и русское солнце взойдет». Украинский сепаратизм в России. Идеология национального раскола. Москва, 1998. 229 с.

38. Степанова Н., Андрієнко Ю. Політична участь у добу постмодерну: українська практика / Н. Степанова, Ю. Андрієнко. Молодий вчений. №5 (20). Ч. 4. травень 2015. С. 125-128.

39. Хома Н. Візуалізація як характеристика постмодерної політичної дії / Н. М. Хома. Гілея. Політичні науки. Збірник наукових праць. 2014. № 89. С. 405-408.

40. Черниш А. Мова та ідентичність у сучасному світі. Мова і суспільство. Львівський університет ім. І. Франка, 2012. Вип. 3. С. 13-22.

41. Шевчук Г., Трач Н. Мовна політика після Помаранчевої революції. Магістеріум. Мовознавчі студії. 2009. Вип. 37. С. 97-104.

42. Шипунов Г. Ідеологія політичних партій: методологічні засади дослідження / Г. Шипунов. Політикус. 2017. Вип. 3. С. 43-47.

43. Шипунов Г. Концептуальні особливості визначення «лівих» та «правих» політичних партій в умовах постіндустріального суспільства. «Грані». 2017. Том 20. Вип. 1 (141). С. 67-73.

\section{References:}

1. Alekseev O. Political hermeneutics as a method of political science research: Abstract. dis. ... cand. flight. Sciences: 23. 00. 01 / Oles Honchar Dnipropetrovsk National University. Dnepropetrovsk, 2008. 20 p.

2. Bowring B. Language rights in practice - the case of the former editor of the only Khakas language newspaper / Lukanovic S. N. (ed.). A Shared Vision: Intercultural Dialogue - A Global Paradigm to Promote Linguistic and Cultural Diversity. Ljubljana, Slovenia: Slovenian National Commission for UNESCO, Institute for Ethnic Studies. 04 Nov. 2010. Pp. 87-106.

3. Brzezinski Z. «The next» hot spot may well be Ukraine». Voice of Ukraine. 15. 08. 08. P. 2.

4. Bilyk B. Problems of the state language in Ukraine (1989-2004). Collection of scientific works of the Research Institute of Ukrainian Studies. K .: Polygraphic Center «Foliant», 2005. T.VI. Pp. 160-164.

5. Bratski A. Ukrainian language issue or the issue of the Ukrainian language - socio-psychocultural aspect. K .: Center for Ukrainian Studies of Kyiv National University named after T. Shevchenko, 2012. Vip. 8. Pp. 86-89.

6. Bunetsky L. Aspects of institutionalism in modern political science: analysis of the phenomenon of «political institution». Bulletin of Kyiv National University. T. Shevchenko. Philosophy series. Politology. Vip. 91-93. 2009. Pp.60-64.

7. Vyshnyak O. Attitude of Ukrainian citizens to the issue of the status of languages in the state. Language situation in Ukraine: between conflict and consensus. K .: IPiEND named after IF Kuras of the National Academy of Sciences of Ukraine. 2008. Pp. 144-157.

8. Gavdida N., Nazarevich L. Linguocide as a form of language policy. Scientific notes of TNPU. Series: Linguistics. Vip. II (24) 2014 78. Pp. 77-80.

9. Gadamer G. - G. Hermeneutics and poetics / G. - G. Gadamer; lane. with him. K .: Universe, 2001. 288 p.

10. Gelman V. Institutional building and informal institutions in modern Russian politics. Polis. Political research. 2003. №4. Pp. 6-25.

11. Gorbatenko V. Postmodern and the transformation of the value basis of human existence / V. Gorbatenko. Political management. Kyiv, 2005. №1. Pp. 3 - 13.

12. Gorenburg D. Soviet Nationalities Policy and Assimilation / D. Arel, B. Ruble (eds.). Rebounding Identities: The Politics of Identity in Russia and Ukraine. Baltimore M D: Johns Hopkins University Press, 2006. Pp. 273-303.

13. Danilevska O. Language in revolution and revolution in language: language policy of the Central Rada, Hetmanate, Directory of the Ukrainian People's Republic / Oksana Danilevska. K., 2009. 176 p. 
14. Derbyshire J. D., Derbyshire J. Political systems of the world: In 2 vols. Volume 1: Per. from English M .: RIPOL KLASSIK, 2004. 512 p.

15. Dziuba I. What is on the horizon? (our cultural heritage and cultural future) / Dziuba I. Ukraine: cultural heritage, national consciousness, statehood. Kyiv: Naukova Dumka, 1992. Issue. 1. Pp. 225-230.

16. Diak I. Ukrainian revival or new Russification?: Scientific publication. K .: Granoslov, 2000. 304 p.

17. Dyomina O. Axiological foundations of the national idea / O. Dyomina. Gilea: scientific bulletin. 2015. Vip. 93. pp. 201-205.

18. Ivanyshyn V. Nation, statehood, nationalism. Drohobych: Renaissance, 1992. 175 p.

19. Klimanska L. Communicative potential in politics / Larisa Klimanska. Ukrainian national idea: realities and prospects of development: [collection of scientific works] / National University «Lviv Polytechnic» [and others]. Lviv: Lviv Polytechnic National University Publishing House, 2006. Issue 18. Pp. 104-109.

20. Kozhevnikov V. A difficult path to the native language. Kyiv, 2005. 27 p.

21. Kolodiy A. The national dimension of social life. Lviv: Astrolabia, 2008. - 368 p.

22. Kresina I. Ukrainian national consciousness and modern political processes: (Ethnopolitical analysis): [Monograph]. K .: Higher school, 1998. 392 p.

23. Lapina T. Identification of culture: philosophical criteria. Philosophy and culture. 2013. № 10. Pp. 1407-1418.

24. Lopushinsky I. Formation and implementation of state language policy in the field of education of Ukraine: Abstract. dis .... dr. flight. Sciences: 25. 00. 02 / National Academy of Public Administration under the President of Ukraine. K., 2008. 30 p.

25. Melnyk O. «The first and third Rome» in the context of the ideology of the «Russian world» and the verification of the modern Vatican / O. Melnyk. Ukrainian religious studies. 2015. № 73. Pp. 311-319.

26. Merkel V. Formal and informal institutions in defective democracies / V. Merkel, A. Croissant. Political research. 2002. №2. Pp.20-31.

27. Novakova O. Parameters of constructive interaction of political forces / O. Novakova. Scientific journal of NPU named after MP Drahomanov. Series 22: Political Science and Methods of Teaching Socio-Political Disciplines. 2014. Vip. 15. Pp. 3-8.

28. Ogienko I. History of the Ukrainian literary language. K .: Our culture and science, 2004. 436 p.

29. Piren M., Rebkalo V. Spirituality of the individual - the main value of a democratic society / M. Piren, V. Rebkalo. Bulletin of the National Academy of Public Administration under the President of Ukraine. 2011. Vip. 2. Pp. 228-236.

30. Political and ideological process in Ukrainian society in terms of modernization: a comparative analysis. [Monograph] / For the general. ed. FM Rudich. K.: IPiEND them. IF Kuras NAS of Ukraine, 2013. 448 p.

31. Postol A. Postmodernism as a modern socio-political reality / A. Postol. Humanitarian Bulletin ZDIA. Zaporozhye, Issue. 42. 2010. Pp. 69-79.

32. Pritsak O. Instead of monologues and polemics - creative dialogue. Chamber. 1994. №4 (25). Pp. 98-107.

33. Savoyska S. Political context of the model of language policy: theoretical and methodological analysis [Text]: monograph / Svitlana Savoyska; Lviv. nat. Univ. Ivan Franko. Lviv: Prostir-M, 2019. 790 p.

34. Savorska E. Political networks in the processes of supranational regulation: European and world experience. M .: IMEMO RAN, 2018 p.

35. Smagulova J. «Language policies of kazakhization and their influencestepion Smagulovaisep.] J. Iternational journal of bilingual education and bilingualism. 2008. 19 Dec. Vol. 11. Issue 3-4. Pp. $440-475$.

36. The Ukrainian question in the Russian Empire (late XIX - early XX centuries.): Collective scientific monograph in three parts. Part 3. Kyiv: Institute of History of Ukraine, National Academy of Sciences of Ukraine, 1999. $276 \mathrm{p}$.

37. Smolin M. «Ukrainian fog must dissipate, and the Russian sun will rise.» Ukrainian separatism in Russia. The ideology of national division. Moscow, 1998. 229 p.

38. Stepanova N., Andrienko Yu. Political participation in the postmodern era: Ukrainian practice / N. Stepanova, Yu. Andrienko. A young scientist. №5 (20). Ch. May 4, 2015. pp. 125-128.

39. Khoma N. Visualization as a characteristic of postmodern political action / NM Khoma. Gilea. Political science. Collection of scientific works. 2014. № 89. Pp. 405-408.

40. Chernysh A. Language and identity in the modern world. Language and society. Lviv University named after I. Franko, 2012. Issue. 3. Pp. 13-22.

41. Shevchuk G., Trach N. Language policy after the Orange Revolution. Magisterium. Linguistic studies. 2009. Vip. 37. Pp. 97-104.

42. Shipunov G. Ideology of political parties: methodological principles of research / G. Shipunov. Politicus. 2017. Vip. 3. Pp. 43-47.

43. Shipunov G. Conceptual features of the definition of «left» and «right» political parties in a post-industrial society. «Faces». 2017. Volume 20. Vip. 1 (141). Pp. 67-73. 